\title{
Relationship to the River: The Case of the Rural Communities Residing Beside the Tembeling, Pahang and Muar Rivers
}

\author{
Bahaman Abu Samah $^{1}$, Sulaiman Md. Yassin ${ }^{1}$, Azimi Hamzah ${ }^{1}$, Hayrol Azril Mohamed Shaffril ${ }^{1}$, Asnarulkhadi \\ Abu Samah ${ }^{2} \&$ Khairuddin Idris ${ }^{3}$ \\ ${ }^{1}$ Institute for Social Science Studies, Universiti Putra Malaysia, Putra Infoport, Serdang Selangor, Malaysia \\ ${ }^{2}$ Faculty of Human Ecology, Universiti Putra Malaysia, Serdang Selangor, Malaysia \\ ${ }^{3}$ Faculty of Education, Universiti Putra Malaysia, Serdang Selangor, Malaysia \\ Correspondence: Bahaman Abu Samah, Institute for Social Science Studies, Universiti Putra Malaysia, Putra \\ Infoport, 43400 Serdang Selangor, Malaysia. E-mail: majudesa.desa3@gmail.com
}

Received: May 23, 2013 Accepted: July 8, 2013 Online Published: September 29, 2013

doi:10.5539/ass.v9n13p119 URL: http://dx.doi.org/10.5539/ass.v9n13p119

\begin{abstract}
The present study attempts to identify the views of the rural community living near to Tembeling-Pahang-Muar river, regarding their relationship with the river. This study is qualitative in nature: a total of three focus group discussions were conducted among selected villagers from Kuala Tembeling, Kuala Tahan and Kundang Hulu villages. Four themes emerged from the analysis, namely sources of income, mode of transportation, less appreciation among the younger generation for the river, and the need for river development. Through the identification of this data, it is a hope that a broader understanding of the relationship between the local community and the river could facilitate river development programmes and strategies.
\end{abstract}

Keywords: river relationship, community development, river development

\section{Introduction}

In modern times, rivers have come to play a less important role in terms of community development. In contrast, rivers were traditionally one of the tools used for regional economic development, as they served as the main route for traders from across the country to come to strategic areas and offer their wares. The advancement of mechanical technologies, such as cars, lorries and motorcycles, and the invention of tar road, have provided a better and more comfortable means of transportation for the community, which has in turn resulted in less dependence on rivers. Such inventions provide avenues for a wider exploration of socio-economic opportunities for the community. In addition, in a local study by Abu Samah et al. (2011), it was reported that the negative attitude, lack of river sources, and environmental changes are the main causes for the waning interest of communities with respect to rivers. However, despite this low interest, there are still a number of communities, particularly those who reside near to the rivers themselves, that still have some kind of relationship with the rivers.

Since few communities still rely on rivers for their socio-economic activities, there is a need to regenerate interest in this natural resource. Many studies on rivers focus on the scientific aspects of them in terms of their content, purity and properties, but give less consideration to social aspects. As a response to this, this study attempts to explore the social aspects of rivers by means of identifying the views of the community on their relationship with rivers. The specific communities considered will be the Kuala Pahang, Kuala Tembeling and Kundang Hulu, who reside near to the Tembeling, Pahang and Muar rivers, in Malaysia.

\subsection{Socio-Economic Activities at the Tembeling, Pahang and Muar Rivers}

Tembeling River is a famous spot for tourism activities, particularly where it flows along the National Park at Kuala Tahan, which enables some of the locals to generate their income via eco-tourism activities. Among the famous eco-tourism activities are water rafting and boat rides. In addition to eco-tourism, locals rely on Tembeling River for its sources of protein such fish and shrimp, and, in relation to this, as a source of side income if there has been a surplus catch. A small portion of locals are identified as river fishermen, either on a full- or part-time basis. Tembeling River is also a mode of transportation for some. A jetty is located at Kuala 
Tembeling River, and tourists can use boat services at this spot to reach National Park at Kuala Tahan. Some locals, particularly those residing near the upper part of Tembeling River in villages such as Mat Daling, Kuala Sat and Bantal, still rely on boats as their main mode of transportation.

Pahang River is still relied on by a number of groups who reside near the river. Pahang River is one of the most famous spots for aquaculture activities, particularly in relation to freshwater species such as Patin (Pangasius Sutchi). Districts such as Pekan and Temerloh are well known for their aquaculture products, and, to the present day, Pahang remains one of the leading states in term of entrepreneurial aquaculture activities and productivity in Peninsular Malaysia (DOF, 2010). Pahang River is also used as a means of transportation. Some members of the community residing near Pahang River, particularly the aboriginal community, use the river as their main route, while a small number rely on its fauna (e.g. fish \& shrimp) for income. Furthermore, water from Pahang River is used by a small number of community members for farming and agricultural activities.

At present, Muar river is used by the locals for their socio-economic activities, particularly recreational onces (Samah et al., 2011). Muar River is a famous spot for fish such as Baung (Mystus spp) and fresh river shrimp. Every year, in certain months, in addition to local anglers, thousands of anglers from states such as Negeri Sembilan, Melaka, Kuala Lumpur and Pahang spend their leisure time looking for fresh fish and shrimp at Muar River. Besides recreational activities, a small portion of the Muar River community relies on the river for their additional income. According to Abu Samah et al. (2011), a small percentage of the community continuously uses fishing (fish \& shrimp) to generate additional income, as the prices of these commodities are relatively substantial. For example, fresh river shrimp from Muar River are estimated to worth between RM17 and RM45 (roughly USD5.5 \& USD15) per kilo, and thus are a good source of income. According to Abu Samah et al. (2011), some locals are also involved in boat rental services for the anglers, which serve as a source of income for them. Muar River is also used for transportation. In villages such as Kundang Hulu, for example, a small boat, locally known as a Kotak, is still used by locals, particularly students and farmers, to cross Muar River.

\section{Methodology}

This study was approached qualitatively using focus group discussion (FGD) as a technique for data collection. A total of three FGDs were conducted at three selected villages located at the Tembeling, Pahang and Muar rivers (Table 1). A qualitative method was employed as the main technique for the data collection as it would allow the researchers to understand the living experience (Creswell, 2007; Marshall \& Rossman, 2011) among the communities residing near the Tembeling, Pahang and Muar rivers, which are associated with their relationship to the river. In addition, the qualitative approach provides rich phenomenological details regarding the subject being investigated in the specific context. The FGDs were conducted by the researchers until saturation point was reached; this indicates that a full understanding of the experience can be obtained, and this understanding will not be altered through further discussion with participants (Laverty, 2003). 
Table 1. Information on the respondents

\begin{tabular}{|c|c|c|}
\hline \multicolumn{3}{|c|}{ FGD1 (duration: 50 mins) } \\
\hline Name & Occupation & Location \\
\hline $\mathrm{R} 1$ & Fisherman & Kundang Hulu - Muar River \\
\hline $\mathrm{R} 2$ & Rubber tapper/part-time fisherman & Kundang Hulu - Muar River \\
\hline R3 & VDSC Secretary - angler & Kundang Hulu - Muar River \\
\hline R4 & Fisherman & Kundang Hulu - Muar River \\
\hline \multicolumn{3}{|c|}{ FGD2 (duration: 70 minutes) } \\
\hline Name & Occupation & Location \\
\hline $\mathrm{R} 1 \mathrm{KT}$ & Village leader - involved in river development plan & Kuala Tembeling - Pahang River \\
\hline R2KT & $\begin{array}{l}\text { Pensioner/forest ranger }-30 \text { years' experience in managing } \\
\text { Tembeling and Pahang rivers. }\end{array}$ & Kuala Tembeling - Pahang River \\
\hline $\mathrm{R} 3 \mathrm{KT}$ & Pensioner (ex village leader) - involved in river development plan & Kuala Tembeling - Pahang River \\
\hline \multicolumn{3}{|c|}{ FGD3 (duration: 88 minutes) } \\
\hline & Occupation & Location \\
\hline R1TH & VDSC Secretary & Kuala Tahan - Tembeling River \\
\hline R2TH & Resort and restaurant manager & Kuala Tahan - Tembeling River \\
\hline R3TH & Resort manager and travel agent & Kuala Tahan - Tembeling River \\
\hline R4TH & Director, Community Eco-Tourism Resource Centre & Kuala Tahan - Tembeling River \\
\hline R5TH & Travel agent & Kuala Tahan - Tembeling River \\
\hline
\end{tabular}

The researchers started the FGDs by introducing the team members and the purposes of the study, followed by self-introductions among the respondents. After the ice-breaking process, the question and answer process began. To ensure the FGDs were conducted in line with the objective, and to maintain the flow of the conversations, an interview protocol was prepared prior to the discussions. The focus of the questions was on the views of the respondents regarding the current status of the river, their relationship with the river, socially and economically, and their expectations or needs for the future. The FGD respondents were selected with the assistance of the three respective village headmen. They assisted in identifying the respondents based on certain criteria: (i) they must have been involved in some kind of river activities in relation to socio-economic activities; (ii) they must have had some kind of involvement in preserving or facilitating the river development plan. The data obtained were later transcribed verbatim and analysed using thematic analysis.

\section{Results and Discussion}

River has long been recognized in both - local and international studies as one of the natural elements that contribute significantly towards the community socio-economic development (Samah et al., 2011; Faiz et al., 2010; Mohamed, 2002; Maroudas \& Kyriakaki, 2011; Harrison \& Schipani, 2008). Similarly, within the scope of this study, it can be concluded based on the discussion made that the locals relationship with their river is based four themes namely: sources of income, mode of transportation, less appreciation among the younger generation for the river, and the need for river development.

\subsection{Sources of Income}

Sources of income was one of the themes identified for further analysis. The discussions have provided a rich information with regard to their relationship to the river in term of money making activities. With the availaibility of natural sources and its potential in tourism, sources of income has been repeatedly informed by the respondents as the main activity conducted at these rivers. Within this theme, three sub-themes have been identified: (i) alternative income sources, (ii) fish rearing, and (iii) eco-tourism.

\subsubsection{Alternative Income Sources}

According to R2KT, only a small number of community members depend on the rivers as sources of income. They perceive that the river provides alternative sources of income, although their catch (fish \& shrimp) is declining compared to earlier years. Abu Samah et al. (2011) has clarified that since the income from the river is not sufficient to guarantee financial support for their families, many villagers opt for other jobs as their main source of income (e.g. government servants, rubber tappers \& farmers). 
Side income, that's what I said earlier, meaning in the morning he went to [the] farm, [then came] back from the farm [via the river], he set his fishing net in place, continued [down] the river [in] his boat, [and] on his way back he lifted the nets, that is his routine ancillary work, meaning that his primary (main job) is rubber tapper. (R2KT)

R4 expressed his agreement with R2KT by stating 'It had to be that way, a way of life to land-dwelling, as mentioned earlier at times we do belat (Note 1) activities, sometimes even up to two'.

Declining river resources and environmental changes have forced the communities to be less reliant on the river as their main source of income. Such declines are unsurprising in Malaysia, as a number of scientific studies have already highlighted similar problems. For example, Chong et al. (2010) found that out of 1,951 species of freshwater and marine fish studied in Malaysia, nearly half are threatened to some degree. Chew and Zulkafli (2012) provided another view by accentuating the need for conservation efforts of species such as Jelawat (Leptobarbus hoevenii), Kelah (Tor tambroides) and Temoleh (P. Jullieni), as these species are now scarce. Water pollution, factory waste, sewage waste, logging, mining and deforestation have been identified as the major contributors to this decline in natural river resources. In addition, Shaffril et al. (2013) and Abu Samah et al. (2012) concluded that climate change may be another possible factor, as unstable water temperatures will cause the death of fauna, or drive them to seek other suitable habitats.

\subsubsection{Fish Rearing}

Aquaculture activities are flourishing, particularly along Pahang and Tembeling Rivers. Pahang, where these two rivers flow, is indeed the leading state in terms of the quantity of aquaculture entrepreneurs, and productivity in Peninsular Malaysia (DOF, 2010). Among the species reared are Pangasius sutchi (locally known as Patin). One of the main reasons why aquaculture activities are actively participated in by locals at these two rivers is that the water is of a high quality and suitability for fish rearing. From another perspective, Ahmad Faiz et al. (2010) reported that aquaculture activities are preferred by locals in Pahang due to the consistent demand for fish, and the ability of such activities to enhance locals' income. In our study, R1KT stressed that he has witnessed the development of aquaculture activities at Pahang and Tembeling Rivers: "I [have] see[n], [...] aquaculture activities [including] fish rearing in cage[s]".

Similarly, R3KT stressed that aquaculture activities are actively conducted at Pahang and Tembeling Rivers:

[At] Kuala Tembeling we have Jelai River, Kuala Pasok, and then Tembeling River also has Pahang River, [which] has [patin and tilapia fish farming].

\subsubsection{Eco-Tourism}

Eco-tourism is a booming industry, particularly along Tembeling River. A portion of Tembeling River flows along a National Park area, where thousands of tourists - both local and international - spend their time. Eco-tourism is regarded as one of the activities that can enhance the socio-economic status of the community (Mohamed, 2002; Maroudas \& Kyriakaki, 2011; Harrison \& Schipani, 2008; Stern et al., 2003). Similarly, in this study area, there are many opportunities for locals. For instance, many have been involved in eco-tourism activities such as boat rides, camping and water rafting at Tembeling River, which have became their main source of income. As pointed out by R1TH:

The importance of rivers also leads to eco-tourism activities. For example, [...] boat rides. Boat ride[s are] one of the important activities for eco-tourism [...]. [This includes] watching boats along the Tembeling River, fishing, camping and water rafting. All river-related activities in eco-tourism are [on] the increase. Especially in recent years, the number of tourist arrivals to the National Park [has been] increasing. In 2010, there were 85,576 tourists, 2011 and 2012 increased to 88,600 and 102,800 people, respectively. So, our tourist arrival graph increases. Meaning, our reliance on the river in [the] eco-tourism sector is increasing.

\subsection{Mode of Transportation}

Physical development has reached remote areas. In addition, community halls, electricity and water supplies and roads provide new forms of communication in many rural areas, which have replaced the traditional role of rivers. Tar roads have become the main preference for the communities, as they save time and offer more comfort to travellers.

People [used to] use [boats] from one village to another [...]. So at that time, this river was just like the current highways. However with the rapid modern development, thing[s] changed. [...] People [prefer to travel via] streets, so [the] river [has become] side lined [and] confined to a place to catch fish. Houses that used to be located near river[s are] now [close] to road[s]. (R1KT)

Nonetheless, in a number of remote areas in Peninsular Malaysia, such as Kuala Tahan, Kuala Tembeling and 
Kundang Hulu, river transportation systems are still needed by the local community. As stated above, in Kundang Hulu, locals use a small boat, or Kotak, to cross the river. The importance of the kotak was stressed by R2:

No, that is inclusive of those who go to farm, people staying here, the garden there, sometimes people from here work there, people from there work here. (R2)

Nevertheless, in some areas, such as Tembeling in Pahang, rivers are still used as 'motorways', not only for locals but also among the aboriginal people who reside inland. Similar to the scenario in Kundang Hulu Village, locals in a number of villages along Tembeling River still rely on boats as a means of transportation: 'For those villages, the boat is the mode of transportation. The above villages [start] from Kampung Pagi' (R1).

Boat services are also provided for tourists at Kuala Tembeling to bring them to the National Park located at Kuala Tahan - a journey that takes three hours. 'That means the National Park (Taman Negara Kuala Tahan) jetty is prepared for foreign tourists' (R2KT).

For many foreign tourists, the experience of travelling in a boat is an exciting event. Thus, they often choose to travel by river (i.e. via boat) instead of by road (i.e. in cars) to travel from one destination to another. This choice, by and large, has helped to maintain the traditional role of the river. R3TH then has expressed his agreement with R2KT by stating 'The local tourists prefer to come by bus. [But] foreign tourists, [...] like [it] here because there are boats'.

\subsection{Less Appreciation among the Younger Generation for the Rivers}

Based on the discussions done, it can be concluded that the younger generation in these three areas are less appreciating the river. Within this theme, a total of three sub-themes have emerged namely education evolution, influence of advance technology and less appreciation to the river.

\subsubsection{Education Evolution}

According to the respondents, the younger generation has less 'communication' with the rivers. According to R1, education evolution in Malaysia has resulted in the younger generation having better educational achievements, and thereby obtaining wider access to higher education. This scenario has led the younger generation to focus on education rather than obtaining experience from river activities.

In my opinion, the highest academic achievement for the old generation was just SPM (Note 2). All young boys prefer to go to public higher institutions [nowadays]. They take lightly on rivers except for their parents. They are more concerned [with] their education. The old[er] generation [is] less educated.

$\mathrm{R} 3$ has in his view has stated that most of the younger generation are migrating to other areas for seeking job that suit their education achievement.

The young people, majority of them have migrated, but most of the olders in this village work as a rubber tapper.

\subsubsection{Influence of Advance Technology}

Gannone (2008) and Halewood and Kenny (2008) have stated that the younger generation are more attached to advanced technologies such as the Internet, computers and mobile phones, which better fit their needs and interests, particularly when it comes to entertainment and this might be the probable example of why they expressed a less interest on the river. R3 seem to agree with this by stating.

For the current generation, they would prefer to be in front of $[\mathrm{a}]$ computer $[\ldots]$ than $[\ldots]$ go to river. To them it is a waste of time going to [a] river, [they would rather play] computer games.

\subsubsection{Less Appreciation to the River}

R2 expressed his frustration regarding the lack of interest among the young generation in relation to rivers by stating: 'They [don't] recognize [...] belat [... and if we] were to give [them] some examples of fish they [wouldn't] recognize [those either]'.

When R2 was asked about the meaning of being a young person who is part of a river community, he stated that these individuals need to at least have some knowledge regarding the river (e.g. the type of fish, its figure, etc.).

That's it, at least we can understand the meaning of [the] river, [such as] what is [in it]. In terms of experience, [the younger generation] don't have any [...]. [At] least, they should know the type and shape of fish in the river.

\subsection{The Need for River Development}

The respondents accentuated the need for river development. Communities in remote areas are always particularly keen to express their hunger for development. A local study conducted by Abu Samah et al. (2011) 
demonstrated the readiness of communities with respect to river development, with two conditions - first, the development must not environmentally harm the river, and second, it must not obstruct the activities they conduct in relation to the river. R1KT stated that concerned parties should turn their attention to river development: 'If we were to revive the importance of [the] river, it can benefit the people. We need to divert from mere land development to also [developing the] river'.

R1KT further added that, with a proper development strategy, the Pahang and Tembeling rivers have huge potential to be developed.

I think both rivers can be developed. With [the] proper planning and strategy. If we look at Malacca River, government over there has placed focus on the river development.

A statement by R4TH also illustrated one of the ways in which rivers can be developed; he accentuated that the development strategies should be in line with proper conservation of the environment:

For example, [with regards to] logging activities, they should have systematic way of doing it. Within a month period they conduct their logging activities in an area and then they re-plant. After that, they will focus on another area and then re-plant.

\section{Conclusion}

It can be concluded that some members of the communities considered in this study still depend on rivers to generate their income. Some of them still fish in the rivers; the number of fish and shrimp is growing increasingly scarce, which has had an effect on income, however the low quantity of these products has increased the price, as the demand remains high. Currently, for example, shrimp from the Muar River are sold for between RM17 and RM45 per kilo (roughly between USD5.4 to USD15 per kilo), while fish such as Jelawat and Patin Muncung from the Pahang or Tembeling rivers are sold for RM400 to RM500 per kilo (roughly equivalent to USD133 to USD166 per kilo). As part of the Tembeling River flows through the National Park at Kuala Tahan, some of the community members are conducting eco-tourism activities by which to generate income. Eco-tourism activities such as boat rides and water rafting have indeed offered a consistent income for the community near Tembeling River, as the National Park has been a central attraction for both local and international tourists.

The main question that arises here is why locals are still relying on the rivers, despite the fact that they are becoming increasingly polluted, and their fauna, particularly fish and shrimp, are declining. A number of causes can be cited for this. First, the strong relationship and 'communication' that has long been established between the villagers and the rivers have created a strong attachment between them, and this has maintained their dependence on the rivers as the source of income. Shaffril et al. (2013) state that demographic factors such as age and duration of residence in an area have a relationship with the attachment locals feel to rivers, and the extent of 'communication' between the community and nature. Shaffril et al.'s (2013) findings seem to explain the local scenario in this study, as the respondents have lived in the villages for long periods of time (in the majority of cases, more than 20 years), which is likely to have created a better relationship and attachment with, and communication between, them and the rivers. The data obtained also suggests that childhood experiences have contributed to these relationships. Unlike to present younger generation, who prefer to spend their time on advanced technologies, the respondents spent much time on physical activities (e.g. fishing, diving \& swimming) at the rivers during their childhood years.

Other demographic factors can also go some way to explaining why the younger generation has less interest in the rivers - for example, less time living in the area and less experience with the rivers. Another possible factor is environmental changes and a lack of resources, which might lead young people away from conducting river-related activities (e.g. swimming and diving in polluted rivers, which might then affect their health). In line with Gannone (2008) and Halewood and Kenny (2008), the younger generation may also have less interest in rivers as they are more attached to advanced technologies such as the Internet, computers and mobile phones, which better fit their needs and interests, particularly when it comes to entertainment. Young people in Malaysia are heavy users of the Internet, with almost one-fifth using the Internet daily, and almost a quarter using it four to five times a week. In addition, a total of $62 \%$ of young people in Malaysian communicate via mobile phone more than five times a day (Malaysian Institute for Research in Youth Development, 2011).

The results of this study demonstrate the views of the community with regards to their relationship with the river in three selected areas. These results might be enriched if communities from other areas are considered. The study served to shed some light on how the rivers should be developed and preserved in the future, if the objective of sustainable living beside major rivers is worthwhile economically, culturally and socially. 


\section{References}

Samah, B. A., Shaffril, H. A. M., D'Silva, J. L., \& Uli, J. (2012). The negative environmental changes on the sea and its impact on the aspects of economic, social and health of the fishermen living in the East Coast Zone of Peninsular Malaysia. American Journal of Environmental Science, 7(6), 534-541.

Samah, B. A., Yassin, S. M., Shaffril, H. A. M., Hassan, M. D., Othman, M. S., Abu Samah, A., \& Ramli, S. A. (2011). Relationship to the river: The case of the Muar River community. American Journal of Environmental Science, 7(4), 362-369. http://dx.doi.org/10.3844/ajessp.2011.362.369

Faiz, A. N. A., Khairuddin, I., Jegak, U., D'Silva, J. L., \& Shaffril, H. A. M. (2010). Aquaculture industry potential and issues: a case from cage culture system entrepreneurs: suggestions for intensification of aquaculture industry. Journal of Social Science, 6(2), 206-211.

Chew, P. C., \& Zulkafli, A. R. (2012). Sperm cryopreservation of some freshwater fish species in Malaysia. In I. Katkov (Ed.), Current Frontiers in Cryopreservation. Retrieved May 21, 2012, from $\mathrm{http} / /$ www.intechopen.com/books/current-frontiers-in-cryopreservation/sperm-cryopreservation-of-some-fr eshwater-fish-species-in-malaysia

Chong, V. C., Lee, P. Y. K., \& Lau, C. M. (2010). Diversity, extinction risk and conservation of Malaysian fishes. Journal of Fish Biology, 76(9), 2009-2066. http://dx.doi.org/10.1111/j.1095-8649.2010.02685.x

Creswell, J. W. (2007). Qualitative inquiry and research design: Choosing among five traditions (2nd ed.). Thousand Oaks, CA: Sage Publications.

Department of Fisheries Malaysia (DOF). (2010). Estimated Value and Aquaculture Production from All Aquaculture System, 1998-2007. Retrieved December 4, 2012, from http://www.dof.gov.my/html/perangkaan/files/Carta\%20utk\%20laman\%20web.pdf

Gannone, S. (2008). 'Twenty-four seven on the computers': girls, ICTs and risk. Gender and Education, 20(4), 361-373. http://dx.doi.org/10.1080/09540250802190198

Halewood, N., \& Kenny, C. (2008). Young people and ICTs in developing countries. Information Technology for Development, 14(2), 171-177. http://dx.doi.org/10.1002/itdj.20093

Harrison, D., \& Schipani, S. (2008). Lao tourism and poverty alleviation: community based tourism and the private sector. Current issues in tourism, 10(2-3), 194-230.

Laverty, S. M. (2003). Hermeneutic phenomenology and phenomenology: A comparison of historical and methodological considerations. International Qualitative Methods, 2(3), 21-35.

Malaysian Institute for Research in Youth Development. (2011). Youth Facts: Media Literacy. Retrieved March 29, 2013, from http://ippbm.gov.my/index.php/component/content/article.html?id=347

Maroudas, L., \& Kryiakaki, A. (2011). The perspectives of ecotourism development in small islands of the South Dodecanese. Anatolia: An International Journal of Tourism and Hospitality Research, 12(1), 59-71. http://dx.doi.org/10.1080/13032917.2001.9687000

Marshall, C., \& Rossman, C. B. (2011). Designing Qualitative Research (5th ed.). Thousand Oaks, CA: Sage.

Mohamed, B. (2002). The Development of Ecotourism in Malaysia - Is It Really Sustainable? Paper presented at the International Year of Ecotourism 2002 Regional Conference in Chiang Mai/Thailand, 3-7 March 2002: Community Based Ecotourism in Southeast Asia.

Shaffril, H. A. M., Samah, B. A., D’Silva, J. L., \& Yassin, S. M. (2013). The process of social adaptation towards climate change among Malaysian fishermen. International Journal of Climate Change Strategies and Management, 5(1), 38-53. http://dx.doi.org/10.1108/17568691311299354

Stern, C. J., Lassoie, J. P., Lee, D. R., \& Deshler, D. J. (2003). How 'eco' is ecotourism? a comparative case study of ecotourism in Costa Rica. Journal of Sustainable Tourism, 11(4), 322-347. http://dx.doi.org/10.1080/09669580308667210

\section{Notes}

Note 1. Belat is a traditional tool usually used on rivers to catch fish or shrimp.

Note 2. SPM refers to the Malaysia Certificate of Education.

\section{Copyrights}

Copyright for this article is retained by the author(s), with first publication rights granted to the journal.

This is an open-access article distributed under the terms and conditions of the Creative Commons Attribution license (http://creativecommons.org/licenses/by/3.0/). 